Relations industrielles

Industrial Relations

\title{
Penalty Standards for Sexual Harassment Offences in
} Unionized Workplaces

Pénalités pour harcèlement sexuel en milieu syndiqué

Las penas standard en casos de faltas relacionadas al abuso sexual en los medios de trabajo sindicalizados

K. Wayne Taylor

Volume 53, numéro 2, printemps 1998

URI : https://id.erudit.org/iderudit/005304ar

DOI : https://doi.org/10.7202/005304ar

Aller au sommaire du numéro

\section{Éditeur(s)}

Département des relations industrielles de l'Université Laval

ISSN

0034-379X (imprimé)

1703-8138 (numérique)

Découvrir la revue

Citer cet article

Taylor, K. W. (1998). Penalty Standards for Sexual Harassment Offences in Unionized Workplaces. Relations industrielles / Industrial Relations, 53(2), 326-341. https://doi.org/10.7202/005304ar

Tous droits réservés (C) Département des relations industrielles de l'Université Laval, 1998
Ce document est protégé par la loi sur le droit d'auteur. L'utilisation des services d'Érudit (y compris la reproduction) est assujettie à sa politique d'utilisation que vous pouvez consulter en ligne.

https://apropos.erudit.org/fr/usagers/politique-dutilisation/ 


\title{
Penalty Standards for Sexual Harassment Offences in Unionized Workplaces $^{1}$
}

\author{
K. WAYNE TAYLOR \\ Department of Sociology, University of Manitoba, Winnipeg, Manitoba.
}

\begin{abstract}
What penalties should be assigned to sexual harassers in unionized workplaces? To identify penalty standards in use, 54 arbitrations of grievances against penalties assigned for sexual harassment in Canada over the period 1985-1995, were examined. The standard penalty for sexual harassment involving sexual assault or language and touching is termination. The standard penalty for sexual harassment involving touching (without language) and language (without touching) is suspension. Standard penalties are varied under a number of conditions. Management can use these standards as guidelines for assigning penalties. Unions will find the standards useful for judging the fairness of the penalty assigned.
\end{abstract}

In a recent examination of strategies to stop workplace sexual harassment (Geller-Schwartz 1994), both management and union contributions identified education, employer policy statements, and increased awareness as high priority. Clear definitions of sexual harassment and discipline for harassers were seen as critical. Also necessary are explicit and effective procedures for filing and investigating complaints. Finally, a description of the responsibilities of both supervisors and employees to curb sexual harassment was thought to be important. (Gallant; 1994; Tellier 1994; Conliffe 1994; Sinclair 1994; Stead 1994). One contributor thought that manage-

1. The author would like to thank the lawyers, union officials and sexual harassment officers in Winnipeg whose observations helped shape this paper. The author acknowledge the financial assistance provided by the Social Sciences and Humanities Research Council of Canada. 
ments should demonstrate concretely that sexual harassment issues were being taken seriously (Sinclair 1994).

While some management writers saw a role for sexual harassment articles in collective agreements, this was a high priority for all union contributors (Riché 1994; McCambly 1994; Pepin 1994; Darcy 1994; Godbout and Vaillancourt 1994; Nash 1994). Union writers also gave attention to the need for special union procedures (without management involvement) to deal with sexual harassment between co-workers where both victim and harasser are union members (McCambly 1994; Pepin 1994; Nash 1994). One method advocated for conflict resolution involved personnel from the union's national office. Only if the in-union methods failed would management and workplace policy become involved (McCambly 1994; Nash 1994).

Given this focus on the larger strategic elements in the fight against workplace sexual harassment, little attention was given to linking types of behaviour defined as sexual harassment to specific penalties. When a respondent's behaviour is found to constitute sexual harassment, how does management determine whether a termination, suspension or transfer is appropriate? If a suspension is selected, how long should it be? Should pay, benefits and seniority be reduced or withdrawn?

After a sexual harassment policy is in place and complaints come forward, these details become important. In addition to the reaction of the victim, the respondent, and the union, a management assigning a penalty has to take into consideration the effectiveness of the penalty in curbing sexual harassment. When penalties are too harsh, grievances are likely, and expensive arbitrations are possible outcomes (Pepin 1994: 128). When penalties are too lenient, they are likely to be ineffective in curbing sexual harassment in the workplace and this can involve significant costs in absenteeism, substandard work, low moral, and the potential loss of highly trained and valued employees (Aggarwal 1992a: 95, 1992b: 308; Tellier 1994: 82; McCambly 1994: 123).

In responding to an assigned penalty, the worker accused of sexual harassment and the union have to assess the seriousness of the offence, the fairness of the penalty, the consequences of accepting or grieving the penalty for the respondent, the complainant, and the workplace, as well as the costs of taking the grievance to arbitration.

In the absence of explicit penalty standards, intuition is relied on both for selecting penalties and formulating a response to the penalties. Without guidelines, penalties assigned by management could seem needlessly harsh to unions; those suggested by unions could seem inadequate to management as well as to victims. This situation may encourage grievances pur- 
sued through to arbitration. With no agreed penalty standards in the workplace, external arbitrators need to be called upon to decide the issue.

This report examines the work of these arbitrators in identifying penalty standards for sexual harassment offences. Arbitrators review the evidence used by management to set the penalty being grieved and the counter evidence used by the respondent and the union to grieve the penalty. Arbitrators who judge the penalty appropriate dismiss the grievance. Those who support a grievance will substitute a less harsh penalty, perhaps completely exonerating the grievant. The awards of arbitrators represent a set of penalty standards in practise. They are a set of third party judgments on the appropriateness of penalties assigned to harassers based on a full review of all the facts.

For a variety of reasons, arbitrators do not increase the harshness of an assigned penalty. This fact represents a shortcoming of this study for determining penalty standards. It seems realistic to assume that the penalties assigned to workplace sexual harassment offences by management would sometimes be too lenient rather than too harsh. It is unlikely that these penalties would be grieved, or if grieved, pursued to arbitration. So the data set employed in this study includes cases where penalties assigned were judged to be appropriate, or too harsh, but none that were too lenient.

\section{DATA AND METHODS}

Sexual harassment arbitration cases were selected from those cases listed in Canadian Labour Arbitration Summaries (CLAS) under the classification "disciplinary offences-work relationships-sexual harassment" for the period 1986-1995. For these years, the 54 cases represent the total population of arbitration cases reported in CLAS involving a grievance against penalties assigned to employees charged with sexual harassment in the workplace.

Provincial and federal jurisdictions in Canada use arbitration as a method of dispute resolution. Arbitrators are required to deposit copies of their written decisions (referred to as awards) with labour relations boards. CLAS has contracted with all of these boards to receive copies of every award. Oversight, error, and heavy workloads may result in delays in the depositing and forwarding of written awards to CLAS for analysis, classification and listing. Officials in CLAS estimated that their list is between 95\% and $99 \%$ complete, but the delays referred to above means that the more recent the date, the greater the likelihood of missing cases. The sexual harassment classification also includes occasional grievances by victims of sexual harassment-cases where the union is grieving management's failure 
to properly administer the collective agreement provisions on sexual harassment. These cases were excluded.

Arbitrator's reports were the source of all information about cases: characteristics of the complainant, the respondent, the offence, the penalty assigned, management behaviour, the quality of evidence, management's handling of the case, the arbitrator's award, changes to the penalty, and other factors thought to be relevant to establishing penalty standards. If any aspect of a case was not mentioned in a report, it was recorded as missing information. For example, management's handling of a case could be seen as "appropriate," "questionable," or "inappropriate" in coding a case. If no mention of management's handling of the case appeared, it was recorded as "missing." We did not assume management's handling of a case was not an issue, but only that it was raised by neither the union nor the management.

\section{FINDINGS}

\section{The Cases}

Figure 1 shows the number of cases by the dates of the commencement of arbitration hearings. ${ }^{2}$ Over the period examined, the number of sexual harassment cases shows a fluctuating upward trend, increasing an average 1.4 cases per year.

\section{FIGURE 1}

Sexual Harassment Penalty Grievances (Canada, 1986-1995)

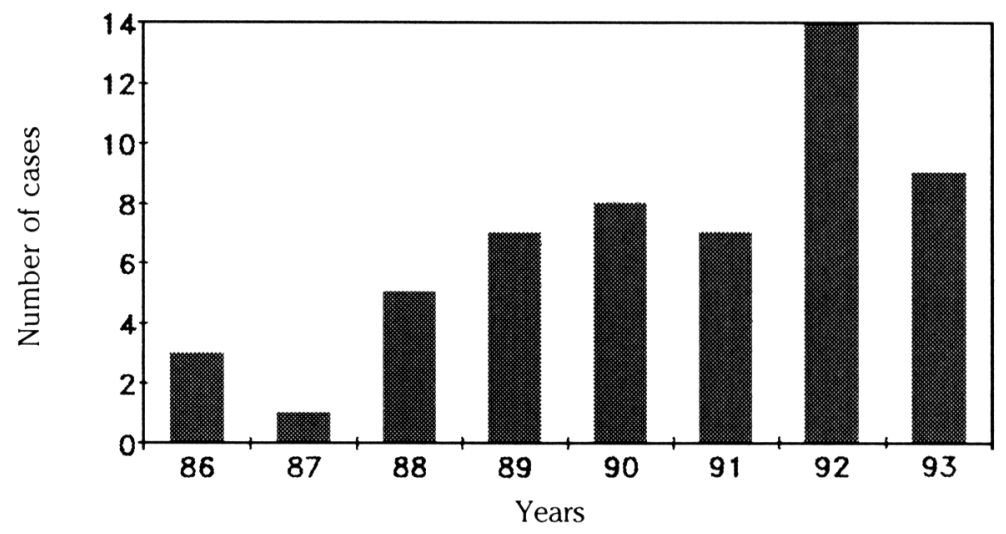

2. None of the cases analyzed had hearing starting dates later than 1993. Delays in filing arbitration reports may be due to oversight, overwork, etc. 


\section{Penalties}

Table 1 shows that management assigned termination penalties to over $70 \%$ of the 54 cases. Arbitrators, on the other hand, upheld termination penalties in about $40 \%$ of cases. Ignoring all other factors, grievants had about 2 chances in 5 of having a termination penalty reduced to a suspension.

TABLE 1

Penalties Assigned to Sexual Harassers by Management and Arbitrators (Percentages)

\begin{tabular}{lcc}
\hline Type of Penalty & Assigned by Management & $\begin{array}{c}\text { Upheld or Assigned by } \\
\text { Arbitrator }\end{array}$ \\
\hline Termination & 70.4 & 40.7 \\
Suspension & 25.9 & 42.6 \\
Transfer & 3.7 & 3.7 \\
Undone & - & 13.0 \\
Total & 100.0 & 100.0 \\
Number & 54 & 54 \\
\hline
\end{tabular}

Arbitrators dismiss grievances (which means they favour management in their decisions) about $60 \%$ of the time. This means that respondents and unions have 4 chances in 10 of having an arbitrator decide that a penalty ought to be reduced. Arbitrators may completely exonerate a grievant and did so $13 \%$ of the time. The probability of a respondent having the penalty undone completely is about 1 in 5 for suspensions, and about 1 in 10 for terminations.

Over the period examined, the trend in the assignment of penalties by management is toward an increasing proportion of terminations. The trend in the penalties adjudicated by arbitrators is toward a balance of suspensions and terminations. At the same time, the trend in the decisions of arbitrators is to dismiss more grievances than they support.

\section{Types of Sexual Harassment}

In Table 2, the offences have been categorized as an approximate guide to the seriousness of the offence. Seriousness rises with the invasiveness and violence involved. Looking offence (leering, peeping) cases involved no language or touching. Language cases ranged from aggressive insults, remarks, and/or pornography, through unwelcome sexual invita- 
tions and expressions of affection. Touching harassment cases varied from aggressive grabbing through rubbing surreptitiously against the victim's body while passing in close quarters. Language and touching harassment cases varied in invasiveness but stopped short of sexual assault.

The most frequently occurring type of sexual harassment in the cases, as shown in Table 2, is language and touching. Language only offences are the next most frequent. Sexual harassment taking the form of sexual assault, touching and looking are relatively infrequent.

TABLE 2

Types of Sexual Harassment

\begin{tabular}{lccc}
\hline Type of Harassment & Number & Percent & Seriousness Index \\
\hline Looking & 2 & 3.7 & 1 \\
Language & 17 & 31.5 & 2 \\
Touching & 5 & 9.3 & 3 \\
Language and & & & 4 \\
Touching & 23 & 42.6 & 5 \\
Sexual Assault & 7 & 13.0 & \\
Total & 54 & 100.1 & \\
\hline
\end{tabular}

The types of harassment shown in Table 2 are arranged in order of increasing seriousness of the offence. ${ }^{3}$ Is there a trend toward more serious offences being brought to arbitration? The numbers in the final column form a rough indicator of the seriousness of an offence. Yearly averages of this indicator increase over the $1985-1995$ period by 0.13 per year. This seems to indicate an upward trend in the seriousness of the offences being taken to arbitration. This finding should be treated with caution. ${ }^{4}$

\section{Workplace Sexual Harassment Policies}

From 1986 to 1989, about $31 \%$ of grievances come from workplaces with a sexual harassment policy in place. From 1990 to 1993 about 54\% orig-

3. Cases were categorized in terms of the most serious offence, which was the major focus in the arbitration hearing. These offence categories were preferred to those utilized in previous research where a single case might be categorized into more than one category (Coles 1989), the categories might not be ordered consistently in terms of seriousness of offence (Terpstra and Cook 1986), or the categories reduced to two (severe/not severe) (Terpstra and Baker 1992).

4. The probability of getting such a trend on the basis of chance alone is 0.07 , somewhat larger than the usual 0.05 criterion. 
inated in such workplaces. The strong trend toward larger percentages of cases coming from workplaces with sexual harassment policies could mean that installing policies increases the frequency of sexual harassment reports. Alternatively, it could mean that workplaces with sexual harassment problems are more likely to bring in explicit policies. The influence of the presence/absence of explicit policies on the rate of sexual harassment complaints requires further study-before/after comparisons on a sample of workplaces, or a survey of with/without workplaces.

\section{Gender of Complaints and Respondents}

Complainants are overwhelmingly female (94\%) and respondents are overwhelmingly male (94\%). In one case a male and a female were victimized.

\section{Relative Workplace Status of Complainants and Respondents}

Table 3 shows that in the workplace about $13 \%$ of victims had a status higher than their respondents and about another third were "peers." About one-third of victims were harassed by respondents with a higher workplace status.

TABLE 3

Workplace Status of Victims and Grievants

\begin{tabular}{lcc}
\hline Victim is & Number of Cases & Percent \\
\hline Superior to Grievant & 7 & 13.0 \\
Peer of Grievant & 17 & 31.5 \\
Subordinate to Grievant & 17 & 31.5 \\
Relative status Unclear & 13 & 24.1 \\
Total & 54 & 100.0 \\
\hline
\end{tabular}

PENALTIES FOR SPECIFIC TYPES OF SEXUAL HARASSMENT

Why are different penalties assigned to the "same offence"? Answers to this question were obtained for each of the types of harassment examined below. Cases were grouped according to the penalties received then each of their characteristics (age, occupational status, any factor that could operate as mitigating and aggravating the offence) were examined one by one for patterns that would explain the different sentences. This method ignores the possibility that two or more factors act together to influence the penal- 
ties. Note that only those factors that would clearly distinguish cases with light and harsh penalties are reported below. ${ }^{5}$

\section{Sexual Assault Offences}

Management assigned termination penalties to 6 of 7 sexual assault cases (see Table 4). Arbitrators agreed with 4 of these and reduced 1 to a suspension. ${ }^{6}$ Grievants had a $60 \%$ probability of receiving a termination for harassment that takes the form of sexual assault.

What factors would explain the assignment of suspension penalties for sexual assaults? The only clear difference found between the suspension and the termination cases was the quality of the respondent's evidence compared to that of the complainant. In the suspension cases, the quality of the victim's evidence was relatively weak in the opinion of the arbitrator. This seems to mean that if arbitrators have questions about the credibility of the case being made by management, suspension is likely to be the arbitrator's choice.

\section{Language and Touching Offences}

Sexual harassment involving language and touching is a serious form of sexual harassment that stops just short of sexual assault. ${ }^{7}$ Cases categorized as assault usually involved the use of hands to touch the victim in a clear attempt to direct or restrain for sexual purposes. In contrast, touching in "language and touching" cases was likely to be "passive." The touching of the victim in one case took place when her male supervisor placed himself in passageways so that body contact occurred when she had to pass through. The supervisor in this case never used his hands to touch the victim or attempted embraces or mouth contact.

Table 5 shows that management assigns termination penalties in about three-quarters (16/22) of these cases. Arbitrators uphold terminations in about two-thirds.

5. It should be made clear that if a factor (such as a record of prior harassment) is not listed as important for distinguishing light from heavy penalties it does not mean that the factor played no role in particular cases. It means only that such a factor did not consistently distinguish cases with light and heavy penalties.

6. The arbitrator saw the seventh case as management overreaction, exonerated the grievant and ordered a reinstatement with compensation for lost wages, benefits and seniority.

7. In categorizing cases as "assault" rather than "language and touching" we used the terms appearing in arbitrator's reports. This in turn depended to some degree upon the incident and how management defined the case. 
TABLE 4

Sample of Sexual Assault Cases

\begin{tabular}{lcc}
\hline Penalty & Assigned by Management & Adjudicated by Arbitrator $^{*}$ \\
\hline Suspension & 1 & 2 \\
Termination & 6 & 4 \\
Total & 7 & 6 \\
\hline
\end{tabular}

* One case where the grievant was completely exonerated by the arbitrator was removed from the sample.

Under what conditions were suspension penalties assigned for sexual harassment involving language and touching? Suspension cases had fewer complainants than termination cases. Grievants who received suspensions had harassed fewer women than those who received terminations: only onethird of suspension cases had evidence that respondents had harassed other women besides the complainant; two-thirds of termination cases had such evidence.

Clear differences were also found in the appropriateness of management behaviour. Arbitrators found management behaviour to be questionable or inappropriate in $50 \%$ of suspension cases, but in none of the termination cases. Inappropriate behaviour included failing to investigate the charges before assigning a penalty, investigations carried out by personnel with a conflict of interest, and other actions that would call the credibility of management into question.

\section{Language Offences}

Table 6 shows that managements assign termination penalties to twothirds of language harassment cases. Arbitrators overturn about half of these and assign termination penalties to less than one-third of cases.

TABLE 5

Sample of Language and Touching Harassment Cases

\begin{tabular}{lcc}
\hline Penalty & Assigned by Management & Adjudicated by Arbitrator $^{*}$ \\
\hline Transfer & 1 & 1 \\
Suspension & 5 & 6 \\
Termination & 16 & 12 \\
Total & 22 & 19 \\
\hline
\end{tabular}

* Three cases where grievants were completely exonerated by the arbitrator were removed from the sample. 
The two most important factors leading to termination penalties were the relative quality of the evidence and the appropriateness of management behaviour. In termination cases the quality of the evidence from the respondent was weak relative to that from the complainant. ${ }^{8}$ In $50 \%$ of the suspension cases, management behaviour was seen by the arbitrators as inappropriate or questionable; it was seen as appropriate in all termination cases.

TABLE 6

Sample of Language Harassment Cases

\begin{tabular}{lcc}
\hline Penalty & Assigned by Management & Adjudicated by Arbitrator \\
\hline Transfer & 1 & 1 \\
Suspension & 5 & 12 \\
Termination & 12 & 5 \\
Total & 18 & 18 \\
\hline
\end{tabular}

Where respondents have sexually harassed complainants with language, suspension penalties are standard. However, where the evidence for the victim is much stronger than for the respondent and management behaviour is appropriate, termination penalties become standard.

\section{Touching Offences and Looking Offences}

Three of the 6 respondents grieving a penalty for sexual harassment involving touching were completely exonerated by arbitrators. The remaining three received suspension penalties. The standard penalty for touching offences is clearly suspension. Of two looking offence cases, one grievant was completely exonerated by the arbitrator and the other received a termination. No conclusions regarding standard penalties should be based on such a small sample. ${ }^{9}$

8. Relative strength/weakness of the evidence was measured by the arbitrator's stated judgment of the credibility of the victim versus the harasser. Completeness of memory and lack of inconsistencies were important in arbitrator's judgment, as were the relative number of witnesses for each side and their credibility.

9. The small number of "looking" cases probably reflects the difficulty of proving its existence (Women's Rights Committee 1980: 12) rather than the frequency of this type of harassment. A 1983 survey of Canadians found the second most frequent type of unwanted sexual attention to be "leering/suggestive looks" (Canadian Human Rights Commission 1983: 5). 
Aggarwal (1991) analyzed Canadian grievance cases over the period 1977-1989. His sample of 31 grievances against penalties assigned for sexual harassment cases includes 12 cases used in the present study. Management assigned termination penalties to $87 \%$ of Aggarwal's cases compared to $70 \%$ in the present study. Only $48 \%$ of Aggarwal's terminations were upheld by arbitrators compared to $58 \%$ in the present study. The $11 \%$ of completely exonerated grievants found by Aggarwal was only $2 \%$ lower than the $13 \%$ found in the present study. Taken together these figures suggest that management's use of termination penalties is becoming less frequent but more effective-in spite of a small increase in complete exonerations, they more often pass the test of arbitration.

\section{SUMMARY OF FINDINGS}

The workplace penalty patterns identified above are the product of the judgment of 46 arbitrators examining facts presented in an adversarial setting in 54 cases over a period of 8 years. Table 7 summarizes the results. ${ }^{10}$ It is reasonable to conclude that the patterns indicate the existence of penalty standards for sexual harassment offences. The patterns have the requirements for a standard: they are consistent, and remarkably so. First, the more serious the offence, the more severe the standard penalty. Second, mitigating and aggravating factors have expected effects: if mitigating factors outweigh aggravating factors, the standard penalty for the type of offence is less severe and vice versa.

\section{APPLICATION OF PENALTY STANDARDS}

We argue here that penalty standards can be an important component in the effectiveness of current strategies for controlling workplace sexual harassment.

10. These findings are roughly similar to those of Terpstra and Baker (1992) who investigated the outcomes of 133 Fair Employment Practices cases heard in U.S. federal courts involving sexual harassment. They found that victims' chances of winning were increased where the harassment was severe, where there were witnesses and supporting documents, and where their employer took no action on behalf of the victim. They also found that victims who had given notice of the harassment to management improved their chances of winning. This feature is not comparable to the present study where all victims reported the harassment. 
TABLE 7

Standard Arbitrator Approved Penalties for Workplace Sexual Harassment Offences

\begin{tabular}{|c|c|c|}
\hline \multirow[b]{2}{*}{ Offence } & \multicolumn{2}{|c|}{ Penalties Upheld or Assigned by Arbitrator } \\
\hline & Standard Penalty & Other Penalties \\
\hline Sexual Assault & Termination & $\begin{array}{l}\text { Suspension if } \\
\text { - respondent's evidence is strong }\end{array}$ \\
\hline Language + Touching & Termination & $\begin{array}{l}\text { Suspension if } \\
\text { - few complainants } \\
\text { - management mishandling }\end{array}$ \\
\hline Language & Suspension & $\begin{array}{l}\text { Termination if } \\
\text { - respondent's evidence is weak; } \\
\text { - no management mishandling }\end{array}$ \\
\hline Touching & Suspension & No other penalties \\
\hline Looking & (Too few cases & to determine a standard) \\
\hline
\end{tabular}

\section{Policy Statements and Collective Agreements}

One primary target of current strategies for reducing and stopping workplace sexual harassment is policy statements (see the introduction). Penalty standards would seem to be a critical component of an effective sexual harassment policy. They link the detailed definitions of sexual harassment to penalty assignment. They permit policy to be applied to the facts of specific harassment incidents in an objective fashion. There are at least three ways that penalty standards can be used in workplace policy statements: (1) Insert a summary of the penalty standards (such as Table 7) directly into the sexual harassment policy document to indicate existing penalty precedents; (2) Attach the standards as an appendix to the main policy document as a guideline for decisions; or (3) Use the standards in the training and awareness materials associated with the policy. Of course, these same possibilities are available for unions who want the standards to become a part of their collective agreements. ${ }^{11}$

\section{Education and Awareness Programs}

Two other primary targets of current strategies for reducing workplace sexual harassment are education and increased awareness. The dissemina-

11. The author is consulting with unions, sexual harassment officers and labour lawyers to develop an accessible statement of the penalty standards that could be used in the ways discussed. 
tion and use of penalty standards through education and awareness programs can be expected to influence workplace sexual harassment in a number of ways. First, employees who are aware of what penalties are likely to follow from specific types of harassment may be less likely to harass. Those who are penalized for harassment are less likely to regard a standard penalty as unfair. Victims of harassment who are aware of the offence/penalty connection are more likely to hold realistic expectations of the outcome of reporting the harassment. It is difficult to know if victim's knowledge of standard penalties would influence the likelihood of reporting an offence.

Second, when all employees, unionized and non-unionized, are educated with regard to penalty standards, they can assess whether management is responding appropriately to complaints about sexual harassment, at least for those cases that go to arbitration. Excessive leniency or harshness will erode confidence in management's ability to deal with workplace sexual harassment.

Third, managers educated with regard to the standard penalties are more likely to select punishments that fit the crimes. If a penalty assignment has to be justified before an arbitrator, staying within these guidelines increases the probability of a successful outcome for management--an award that dismisses the respondent's grievance.

Fourth, union leadership informed about penalty standards for sexual harassment offences are less likely to misjudge the harshness of penalties assigned to members charged with harassment. If an assigned penalty is too harsh for the offence, the union can pursue a grievance through to arbitration with a good probability of a reduced penalty. If the penalty is standard (or too lenient) for the offence, union support of the respondent need not continue past the point of investigation and the performance of their legal obligation to "fairly represent" their members (Darcy 1994, Pepin 1994).

Managements and unions both educated on standard penalties will begin in "the same ballpark" to negotiate appropriate discipline during the grievance process. In these circumstances, finding a penalty acceptable to both parties is less likely to require a lengthy and expensive arbitration.

Union members made aware of penalty standards can determine if union leadership is wasting resources by taking grievances over penalties that fit the sexual harassment offence all the way to arbitration.

Finally, educating the general public about the penalty standards operating in unionized workplaces can reduce the possibility of a public relations miscarriage. The ability of both management and union leadership to refer to existing standards to explain their positions should be helpful when 
difficult cases come to public attention. In this regard, it is useful for everyone to know that these standards represent a rough consensus developed by arbitrators operating under provincial and federal labour legislation. If the standards need changing, the only direct way to do this is via legislation and regulation of the arbitration process and the education and training of arbitrators.

Even if knowledge of penalty standards had only half the influences postulated above, their insertion into policy statements and use in education and awareness programs would still be worth the effort. A workforce informed about the problem of sexual harassment and confronted with a policy that spells out the penalties of harassment can begin eliminating sexual harassment from the workplace.

\section{REFERENCES}

AGGARWAL, Arjun P. 1991. "Arbitral Review of Sexual Harassment in the Canadian Workplace.” Arbitration Journal, March, 4-16.

AGGARWAL, Arjun P. 1992a. Sexual Harassment: A Guide for Understanding and Prevention. Toronto: Butterworths.

AgGaRWAL, Arjun P. 1992b. Sexual Harassment in the Workplace. Second edition. Toronto: Butterworths.

CANADIAN HUMAN RightS COMmission. 1983. Unwanted Sexual Attention and Sexual Harassment: Results of a Survey of Canadians.

COLES, F. S. 1986. "Forced to Quit: Sexual Harassment Complaints and Agency Response." Sex Roles, 14, 81-95.

Conliffe, Roy. 1994. National Grocers' Workplace Harassment Policy. Human Resources Development Centre: Ottawa, 87-95.

DARCY, Judy. 1994. Sexual Harassment: Unions at Work. Human Resources Development Centre: Ottawa, 131-139.

GALlant, Marlene. 1994. A Cooperative Approach to Combatting Sexual Harassment in the Workplace. Human Resources Development Centre: Ottawa, 75-81.

GELLER-SCHWARTZ, Linda. 1994. From Awareness to Action: Strategies to Stop Sexual Harassment in the Workplace. Human Resources Development Centre: Ottawa, 3-10.

GodBout, Clément and Lauraine VAILLANCOURT. 1994. The Commitment of the FTQ to Eliminating Sexual Harassment. Human Resources Development Centre: Ottawa, 139-145.

MCCAMBlY, James. 1994. Sexual Harassment: A Comprehensive Approach. Human Resources Development Centre: Ottawa, 121-125.

NASH, Peggy. 1994. Dealing with Sexual Harassment: The Approach of the $C A W$. Human Resources Development Centre: Ottawa, 145-152. 
PEPIN, Marie. 1994. The CNTU's Policies on Sexual Harassment. Human Resources Development Centre: Ottawa, 125-131.

RicHÉ, Nancy. 1994. Creating Harassment-Free Zones. Human Resources Development Centre: Ottawa, 117-121.

SINCLAIR, Helen. 1994. Sexual Harassment Policies in Canada's Banks: Eliminating Harassment through Cultural Change. Human Resources Development Centre: Ottawa, 95-99.

STEAD, Jo-Anne. 1994. Sexual Harassment in the Construction Industry. Human Resources Development Centre: Ottawa, 99-107.

TERPSTRA, D. and S. COOK. 1986. "Complaint Characteristics and Reported Behaviors and Consequences Associated with Formal Sexual Harassment Charges." Personnel Psychology, Vol. 38, 559-574.

TERPSTRA, D. and D. D. BAKER. 1992. "Outcomes of Federal Court Decisions on Sexual Harassment." Academy of Management Journal, Vol. 35, No. 1, 181-190.

TELliER, Marie. 1994. Sexual Harassment at CN: A Clear Policy and Concrete Action. Human Resources Development Centre: Ottawa, 8187.

Wharton, Etta. 1994. If You Don't "Get It" You Can't Stop It. Human Resources Development Centre: Ottawa, 107-115.

WOMEN'S RIGHTS COMMITTEE OF THE BRITISH COLUMBIA FEDERATION OF LABOUR. 1980. Sexual Harassment in the Workplace.

\section{RÉSUMÉ}

\section{Pénalités pour harcèlement sexuel en milieu syndiqué}

Malgré l'intérêt croissant envers le harcèlement sexuel au travail, on a fait peu de cas des normes de pénalités, c'est-à-dire des normes liant des types de comportement à des pénalités spécifiques. Lorsque quelqu'un est trouvé coupable de harcèlement sexuel, comment un employeur détermine-t-il si un congédiement, une suspension ou une mutation constitue la mesure appropriée ? S'il choisit la suspension, quelle doit en être la durée? Est-ce que le salaire, les avantages sociaux ou l'ancienneté devraient être suspendus ou retirés?

En l'absence de normes explicites de sanctions, l'intuition a servi de guide aux employeurs dans le choix des pénalités. Les syndicats ont fait de même dans leur réponse. Telle situation a encouragé le dépôt de griefs menés jusqu'à l'arbitrage. Faute de normes négociées de sanctions à l'inté- 
rieur du milieu de travail, on a eu recours à des arbitres externes pour décider en cette matière.

C'est le travail de ces arbitres que nous examinons ici. Les sentences arbitrales représentent un ensemble de jugements de tiers sur la pertinence des sanctions imposées aux harceleurs à partir d'un examen complet de tous les faits.

Nous avons sélectionné nos cas d'arbitrage à partir de ceux apparaissant dans le Canadian Labour Arbitration Summaries (CLAS) de 1986 à 1995 sous la rubrique mesures disciplinaires - relations du travail - harcèlement sexuel. Ces cas représentent l'univers des décisions rendues entre 1986 et 1995 pour ces griefs contestant des sanctions imposées à des employés accusés de harcèlement sexuel en milieu de travail.

Les tendances des sanctions ici identifiées proviennent de 46 arbitres s'étant prononcés dans 54 causes sur une période de huit ans. De cela, nous déduisons que pour l'agression sexuelle, la sanction type est le congédiement. On y observe aussi des suspensions dans ces cas où la preuve du défendeur est forte. Quant à la combinaison attouchements et langage, la norme est aussi le congédiement. On y retrouve cependant aussi la suspension s'il y a eu peu de plaintes ou si l'employeur n'a pas bien géré le dossier. Quant au langage déplacé seulement, la sanction type est la suspension. Cependant, on y retrouve aussi le congédiement dans ces cas où la preuve du défendeur est faible et où l'employeur a bien géré le dossier. Quant aux attouchements, ils méritent habituellement une suspension. Il existe trop peu de cas de voyeurisme pour établir une tendance.

Les normes de sanctions constituent une composante critique d'une politique efficace contre le harcèlement sexuel. En établissant un lien entre des définitions détaillées de formes de harcèlement sexuel et la détermination des sanctions, ces normes permettent une application objective de la politique à des faits spécifiques de harcèlement sexuel.

Il y a au moins trois façons dont telles normes de sanctions peuvent être utilisées dans des énoncés de politique en milieu de travail : tout d'abord en insérant un résumé des normes de sanctions directement dans le document traitant de la politique de harcèlement sexuel afin de souligner les précédents en telle matière de sanction. Ensuite, en annexant ces normes au document présentant la politique générale comme guide pour les décisions à venir. Finalement, en utilisant ces normes dans les documents de formation et de sensibilisation annexés à la politique. Ces mêmes possibilités s'offrent aux syndicats qui désirent que de telles normes deviennent partie de leurs conventions collectives.

Un milieu de travail informé du problème de harcèlement sexuel et confronté à une politique qui présente les sanctions en cette matière peut 
commencer à se débarrasser du problème de harcèlement sexuel au travail.

\section{RESÚMEN}

Las penas standard en casos de faltas relacionadas al abuso sexual en los medios de trabajo sindicalizados

Que tipo de penas deben ser aplicadas a las personas que cometen abusos sexuales en el medio de trabajo ? Para identificar las penas standard que se utilizan, 54 casos de abuso sexual en Canadá 1985-1995 fueron examinados. La pena standard por delitos de abuso sexual involucrando asalto o lenguaje y contacto físico es la terminación del contrato de trabajo. La pena standard para el abuso sexual involucrando contacto físico (sin utilización de lenguaje) y lenguaje (sin contacto físico) es la suspensión. Las penas standard también mostraron una cierta variación dependiente de las condiciones propias del caso. La dirección puede utilizar estos standares como bases para la implementación de penas dentro de sus propias instituciones. Los sindicatos encontraran el estudio útil para juzgar la justicia de las sanciones impuestas. 